\title{
MULTIPLE CRITERIA MODEL FOR PROVING INVESTMENT AND CONSTRUCTION PROJECT EFFICIENCY
}

\author{
Stetsenko S. P.
}

\section{INTRODUCTION}

The work is based on the research of leading scientists in the field of investment science and construction economics, presented in the monographs and articles by A. Gojko, L. Sorokina, V. Fedorenko, P. Kulikov, G. Rizhakova, I. Ivahnenko, O. Tugaj, T. Vlasenko, O. Bielienkova, K. Izmajlova та ін. The analysis of literature sources reveals that the individual means of project economic evaluation while building construction investment portfolio do not take into account complex investment risks, differentiated by their individual types, as well the liquidity of developer's future assets, which significantly limits the ability to make informed decisions.

It is revealed that the concept of «liquidity» in the investment process is synthetic and requires a double reflection on different objects:

- in relation to investment objects, liquidity should be linked to the need to assess construction investment assets for their compliance with the planned values at all stages of the construction investment project implementation - from unfinished construction to finished construction products - and, further, to the object of profitable commercial use or social purpose $^{1}$;

- the second important aspect of the concept of «liquidity» is related to the need to evaluate the reliability of the investor as a leading subject of the investment and construction process as for the ability to achieve real investment goals by providing the appropriate level of liquidity balance and solvency of the organization in terms of 4 group indicators ${ }^{2}$.

This interpretation of the category of «liquidity» and the analysis of literature in several groups allowed us to formulate a scientific hypothesis of this work, which is as follows: "A leading requirement in providing a business process of real investment is a high level of liquidity of

\footnotetext{
${ }^{1}$ Izmajlova K.V. Finansovyj analiz: Navchalnyj posibnyk - 2-ge vydannya, stereotypne K.: MAUP, 2001. $-152 \mathrm{~s}$.

${ }^{2}$ Metodika zabezpechennya platospromozhnosti investora, likvidnosti aktiviv proektiv ta yih socialnoyi efektivnosti na bagatokriterialnij osnovi / V. O. Pokolenko, G. V. Lagutin, A. V. Shpakov ta in. // Zb. nauk. pr. «Komunalne gospodarstvo mist». - Harkiv: HNAMG, 2007. - Vip. 78. - S. 70-78.
} 
construction project assets and solvency of the investor". Therefore, in order to formulate a portfolio of construction projects, a new calculation and analytical multicriteria methodology should be proposed which will combine the criteria of liquidity of construction project assets, solvency, and social efficiency. The innovation base should be made up of innovative economic models. The applied result of the created models should be a technique embodied in a convenient methodological complex of applications for target users. Theoretical models and a complex of applications are designed to build rational investment portfolio in terms of volume, sources of financing, level of liquidity and profitability, as well as to ensure the proper level of liquidity and solvency of the organizations implementing construction investments. Therefore, the purpose of the article is to analyze the existing theoretical and methodological approaches to coordination of liquidity and efficiency of construction investments and solvency of investors, as well as to improve existing methods.

\section{Analysis of existing approaches, methods, and models to determine the investment priorities of the composition and structure of the investment portfolio}

The efficiency of investment activity depends on the level of capital construction development, investment, and industrial and construction complexes, which, in turn, is conditioned by production potential of their material and technical base, qualification of contractors, scientific and technical level of design decisions, status of investment process organization and planning, of providing it with financial resources. In the monograph ${ }^{3}$, the issues of revitalization of investment activity are related, first of all, to the need to transform the effective market mechanisms in the construction complex and to improve the economic and technological structure of investments. Among the main areas of « investment process restructuring» are the following ${ }^{4}$ :

1. Investment activity should be built on a single criteria basis: economic, environmental, social.

2. A clear distinction must be made between the areas of use of centralized and decentralized investment in their interconnection.

3. Reducing the duration of the investment cycle (3-4 times or more).

4. Improvement of the industrial, regional and technological structure of capital investments.

5. Increasing sources of investment.

\footnotetext{
${ }^{3}$ Investicijno-innovacijnij rozvitok pidpriyemnickoyi diyalnosti v Ukrayini. Monografiya / V. Fedorenko, P. Kulikov, G. Rizhakova, I. Ivahnenko. - 2019. - K. - 429 s.

${ }^{4}$ Shlyahi pidvishennya investicijnoyi diyalnosti v Ukrayini.: Monografiya./ za zag. redakciyeyu V.G. Fedorenka. - Nizhin: Aspekt-Poligraf, 2003. - 724 s. C. 34.
} 
6. Consistent decentralization of investment process, introduction of investment insurance system.

In Ukraine, at the present stage of economic development, intensification of financial and credit and investment markets is the main condition for the investment activity efficiency. Economic enhancement and investment activity can only be achieved through the creation of capital market. This task is multifaceted and contains both short-term and long-term aspects related to solving the problem of development of the equity and government securities markets. The latter is achieved through promotion of revenues and investments, as well as privatization funds.

Moreover, while building a rational composition of the investment portfolio, it is necessary to revise the criterion-parameter base.

The existing inappropriate approaches to building a construction investment portfolio (a complex of construction projects) mean to apply a traditional set of investment parameters that correlate the volume and pace of investment with the corresponding characteristics of net cash flows ${ }^{5}$.

Comparison of the above classification with the existing traditional system of economic feasibility of the construction investment portfolio allows us to claim that it is essential to improve the system of indicators (factors), used to analyse such a multidimensional category as risk of the corporate investment portfolio, there is a need to rationalize assessment characteristics while developing mathematical model. Since each of the existing quantitative investment risk assessment approaches such as flow comparison methods ${ }^{6}$, optimization methods and models, analogy method, sensitivity method, simulation modeling methods ${ }^{7}$, etc. do not provide a full appropriate assessment and growing requirements for the veracity of results, while developing economic models - theoretical research results and methods - practical research results - the benefits of each approach should be integrated.

One group of sources optimizes the investment structure by improving the organizational and technological decisions of investment projects and changing the negative component of the main project variable - net project income, saving from early commissioning of project fixed assets, as well as by organizational and technological distribution of project investment

${ }^{5}$ Fedorenko V. G., Gojko A. F. Investoznavstvo. / Za nauk. red. V. G. Fedorenka. - K.: MAUP, 2004. $-408 \mathrm{~s}$.

${ }^{6}$ Zelcer R.Ya. Innovacijni modeli i metodi organizaciyi, upravlinnya i ekonomichnoyi ocinki tehnologichnih procesiv budivelnogo virobnictva Kiyiv: «MP Lesya», 2018. 209 s.

${ }^{7}$ Izmajlova K. V., Byelyenkova O. Yu. Imitacijne modelyuvannya rozvitku budivelnogo pidpriyemstva [Elektronnij resurs] // Problemi sistemnogo pidhodu v ekonomici. - 2007. Vip. 4.- Rezhim dostupu: http : // www. nbuv. gov. ua/ e-journals / PSPE/20073/Belenkova_307.htm 
intensity in a manner suitable for the investor (providing in this regard sets of work transitivity requirements, safety requirements, standards of duration and labor intensity. The problem can be represented as follows:

$$
\begin{gathered}
\left\{\boldsymbol{\Omega}_{\mathbf{T}}^{\text {org }}(\mathbf{i})=\Delta \mathbf{P}^{+}(\mathbf{0}) *\left(\left[\Delta \mathbf{t}^{(\mathbf{P}-\ln v)}(\mathbf{0})-\Delta \mathbf{t}^{(\mathbf{P}-\ln v)}(\mathbf{i})\right] * / 365\right) * \boldsymbol{\alpha}\right\} \rightarrow \max , \\
\left\{\boldsymbol{\Omega}_{\mathrm{i}}^{\mathrm{org}}(\mathbf{i})=\text { ЧДД(i)- ЧДД (0) }\right\} \rightarrow \max ,
\end{gathered}
$$

$\mathbf{\Omega}_{\mathbf{T}}^{\text {org }}$ - the expected calculated effect of the implementation of the i-th option of the calendar investment plan, obtained by reducing the duration of development of investments and, therefore, by reducing the lag $\Delta \mathbf{t}^{(\mathbf{P}-\ln \mathbf{v})}$ in this option, compared with the original;

$\mathbf{\Omega}^{\mathbf{o r g}}$ - the expected intended effect obtained by changing the intensity of investment development from the implementation of the i-th option of the calendar investment plan, which leads to a comparative decrease in the negative NVP share, and, consequently, to the increase of the net consolidated income under this variant organizational and technological model implementation of the investment development plan;

$\Delta \mathbf{t}^{(\mathbf{P}-\ln \mathbf{v})}(\mathbf{0}), \Delta \mathbf{t}^{(\mathbf{P}-\mathbf{l n} \mathbf{v})}(\mathbf{i})$ - deferral lag duration of the project operational phase (in days) according to the initial and $\mathrm{i}$-th variant of the calendar plan;

$\boldsymbol{\alpha}$ - the calculated annual rate of discounting of investment flows (in unit particles);

$\Delta \mathbf{P}^{+}(\mathbf{0})$ - is the share of net payment flow from the sale of finished project product received for the released duration $\left[\Delta \mathbf{t}^{(\mathbf{P}-\ln \mathbf{v})}(\mathbf{0})-\Delta \mathbf{t}^{(\mathbf{P}-\ln \mathbf{v})}(\mathbf{i})\right]$ of the investment cycle.

These approaches do not take into account the impact between the main components of the project profitability and do not provide for the establishment of a calculated correlation between them, nor do they give reason to establish the investment priorities of the projects and to select projects in the investment portfolio, since their purpose is organizational and technological improvement of the performance of works calendar plan (development of investments) on the project ${ }^{8}$.

But this does not take into account the stochastic nature of the development of the investment situation, both in terms of the rate of investment development and the intensity of net cash flow receipts and the deferral lag $\Delta \mathbf{t}^{(\mathbf{P}-\ln \mathbf{v})}$.

The following group of sources gives grounds to set investment priorities for a fixed distribution of the components of net and net discounted income.

\footnotetext{
${ }^{8}$ Titok V. V. Formuvannya modeli zhitlovogo budivnictva v misti. Shlyahi pidvishennya efektivnosti budivnictva v umovah formuvannya rinkovih vidnosin. Kiyiv : KNUBA, 2013. Vip. 30. S. 90-99.
} 
According to one criterion (net or net consolidated income, profitability index, etc.), they set investment priorities and, depending on them, build up an investment program for the period, depending on the investment opportunities ${ }^{9}$.

The following approach proposes to use an integral criterion, which, on the basis of a combination of different investment indicators (selection criteria), gives grounds to set investment priorities. The formulation of the project selection task under this approach can be integrated as follows:

$$
\begin{gathered}
\operatorname{IKR}(\mathbf{i})=\left\|\mathbf{M a t r}_{\mathbf{i j}}\right\| *\left|\boldsymbol{\rho}_{\mathbf{j}}\right| *\left|\xi_{j}\right|, \quad \mathbf{i}=\mathbf{1}-\mathbf{n}, \quad \mathbf{j}=\mathbf{1}-\mathbf{m}, \\
\sum_{\mathbf{i}} \mathbf{B S}^{\ln \mathbf{v}}(\mathbf{i})<\mathbf{W}^{\ln \mathbf{v}}, \\
\mathbf{i}=\mathbf{1}-\mathbf{N}^{\wedge}, \quad \mathbf{N}^{\wedge}<\mathbf{n} .
\end{gathered}
$$

where IKR(i) - is the integral indicator (estimated criterion) of the priority of the $\mathrm{i}$-th project among their initial set $\mathrm{n}$;

$\mathbf{B S}^{\ln \mathbf{v}}$ - the total value (volume) of investments that the investor is able to provide during the settlement period;

$\mathbf{N}^{\wedge}$ - number of projects selected from the total volume by the prevailing IKR (i);

$\left\|\operatorname{Matr}_{\mathrm{ij}}\right\|$ - matrix of project evaluation by the criteria indicators (j) in their natural dimension (the columns of the matrix may be net consolidated income, profitability index, specific marginal revenue per unit of the project finished product, payback period, etc.);

$\left|\boldsymbol{\rho}_{\mathbf{j}}\right|$ - a vector that provides a transition from the natural dimension of $\mathbf{D}^{\mathbf{i n t}}{ }_{\mathbf{j}}$ to a single dimension and the consistency of $\mathbf{D}^{\mathbf{i n t}}{ }_{\mathbf{j}}$ growth direction with that of an integrated assessment of the IKR (i) project priority;

$\rho-$ a vector of weight rates that provide specific contribution of individual indicators to the integral $\mathbf{C} \mathbf{r}^{\text {int }}$ score.

In order to expand methodological tools in the construction economy, interesting innovative econometric approaches proposed for other industries were considered, and being flexible enough, they can be successfully used for construction industry. The following groups of sources are to be mentioned $^{10}$ :

\footnotetext{
${ }^{9}$ Tugaj O.A., Vlasenko T.V. Vdoskonalennya proektu na osnovi pidvishennya efektivnosti investicijnoyi diyalnosti / Shlyahi pidvishennya efektivnosti budivnictva $\mathrm{v}$ umovah formuvannya rinkovih vidnosin: zb. nauk. prac.-Kiyiv: KNUBA, 2019.- Vip. 39 u dvoh chastinah. Chastina 2. Tehnichnij. - S. 150-154.

${ }^{10}$ Bielienkova, O. Iu. (2007). Systema metodiv upravlinnia rozvytkom budivelnoho pidpryiemstva [System management development construction company]. Ekonomika ta derzhava - Economy and State, 9, 38-42 [in Ukrainian].
} 
- economic models of game theory implementation for building a rational portfolio of construction projects and sets of works;

- investment criteria balance method;

- modernized factor analysis method for building economic and mathematical model of effective management of enterprise's business and economic activity;

- correspondence matrix of production and financial resources, submitted in the works;

- econometric and diagnostic models designed to identify the leading factors of construction organization restructuring;

- the criteria to determine a degree of contractor risk proposed in the paper $^{11}$;

- search for a statistical criterion for the consistency of technological solutions from the complexity and duration of the BIS;

- search of statistical criterion for optimization of the calendar model of the housing construction industry, which includes several projects;

Outlined in the works of Pokolenko V.A. ${ }^{12}$ method of investment criteria balance initiates a specific methodology for creating construction investment cycle. This methodology in a single algorithm provides rational diagnostics of projects taking into account their profitability, volume and structure of investments, investor strategy and investment market business conditions, with further scenario-stochastic algorithm of pre-selection and final selection based on a new system of criteria. The final component of the method is the development and multi-criteria optimization of the calendar program for project implementation on several criteria, which increase stability of the organization - investor, high financial stability, maneuverability, return on assets and structure of investment cycle financing sources.

A significant step of updating the calculation and criterion base of creating a construction investment portfolio on a multicriteria basis is the work of Ryzhakova G.M. ${ }^{13}$, which suggested the investment framework foundation, alternative to the traditional approaches, and its multicriteria and phased economic diagnostics.

11 Ekonometrichnij instrumentarij upravlinnya finansovoyu bezpekoyu budivelnogo pidpriyemstva : [monogr.] / za nauk. red. d.e.n., prof. L. V. Sorokinoyi. - K. : Kiyivskij nacionalnij universitet budivnictva i arhitekturi; Krivij Rig : Vid. FOP Chernyavskij D. O., 2017. - C. 4-26.

12 Pokolenko V.O. Stohastichnij algoritm racionalizaciyi investicijnogo portfelya // Mizhvidomchij naukovo-tehnichnij zbirnik «Budivelne virobnictvo». - K.: NDIBV, 2002 № 42. - S. 74-77.

${ }^{13}$ Rizhakova G.M. Teoretichni osnovi ta praktichni algoritmi formuvannya portfelya budivelnih investicij shlyahom optimizaciyi obsyagiv ta strukturi podatkiv // Zbirnik naukovih prac Mizhnarodnogo institutu upravlinnya. - K.: MIU, 2005. 
As the first stage of rationale for composition and structure of construction investment portfolio ${ }^{14,15}$ offers a complex economic diagnostics of the separate projects suggested for the portfolio, considering variability of the change of their cost parameters during the investment cycle. The parameters to be varied at this stage are the leading cost indicators in the preinvestment and investment phase, direct and administrative-management costs for the types of works and sections of the consolidated budget, and, in the operational phase, these are indicators of business activity and financial stability of the studied object. Dependent variables (evaluation criteria) in the first stage are a minimum of variations in cost parameters based on the results of estimation of possible scenarios for the development of the investment situation using a random variable generator. This stage includes the development of a risk matrix, the columns of which are heuristically established stylistic descriptions of risks, and the rows of the matrix correspond to the list of arguments of situational variables. Depending on the level of risk, both the range of deviations and the frequency of nontypical events that do not comply with the directive ones change. With the help of a random variable generator, it is suggested to provide arguments to the model of variational values, taking into account the range and frequency set by the deviation matrices. The final operation of this step is to calculate the variation of cost parameters. On this basis, projects are approved or rejected by the investor.

In the second stage, the preliminary-formed construction investment portfolio is subject to optimization by several criteria - the objective functions. The minimum criteria for project taxation included in the portfolio and the criterion of investor reliability - the maximum amount of direct working assets - were selected as the leading criteria. The arguments for these criteria are the volume of project assets by type and the speed of their transformation over time.

The above methodological approaches to the investment project evaluation serve as a methodological prerequisite for improving the system of socio-economic efficiency of investments on a multicriteria basis ${ }^{16,17,18}$,

${ }^{14}$ Rizhakova G.M. Optimizaciya obsyagiv ta strukturi podatkiv yak kriterialna osnova viyavu formuvannya investicijnih program, ekonomiko-teoretichnij zmist ta programna realizaciya metodiki. // Naukovo-virobnichij zhurnal «Zemlevporyadnij visnik», № 4, 2005. - S. 79-81.

15 Tetyana Marchuk, Dmytro Ryzhakov, Galyna Ryzhakova and Sergiy Stetsenko (2017). Identification of the basic elements of the innovationanalytical platform for energy efficiency in project financing. Investment Management and Financial Innovations Vol. 14(4), pp. 12-20.

16 Mihels V.O., Bondar V.P. Ob'yednana strategiya ekonomichnogo upravlinnya pidpriyemnickim proektom: Monogr. /Pid zag. red. V.O.Mihelsa. - K.: KNUBA, 2003. - $200 \mathrm{~s}$.

${ }^{17}$ Gojko A. F. Metodi ocinki efektivnosti investicij ta prioritetni napryami yih realizaciyi / A. F. Gojko. - K. : Vira-R, 1999. - 320 c.

${ }^{18}$ Vahovich I. V. Sistema ekonomichnih metodiv optimizaciyi budivnictva : Avtoref. dis... kand. ekon. nauk : 08.07.03 / I. V. Vahovich; Kiyiv. nac. un-t bud-va i arhit. - K., 2004. - 19 c. 
emphasizing the need to take into account such factors as assets liquidity and solvency of the investor ${ }^{19}$.

\section{Economic and mathematical model of liquidity management of construction investment assets and ensuring their social efficiency on a multicriteria basis}

The ongoing process of structural transformation of the economic complex of the country, are followed by the need to reorganize the structure of real investments. This requires creation of such methodological and methods approaches to cost-effective diagnostics, selection and implementation of real investments, aimed not only at providing high term return for the investor, but also providing all participants of the investment process with the opportunity to carry out reliable and economically justified monitoring of the flow of assets and sources of construction investment projects and ensure high project liquidity, profitability and social efficiency. Existing techniques and models, as demonstrated in the first section of the paper, do not meet these requirements, focusing mainly on commercial appeal and using the traditional set of investment project evaluation indicators.

The need to create innovative theoretical and methodological foundations, which efficiently adjust the tasks of assessing the liquidity, profitability and social efficiency of construction investments, determines the scientific, theoretical and applied relevance of the proposed model.

Within the group of methods considered in a number of works ${ }^{20,21,22}$, the organization solvency and the liquidity of its balance are defined. Solvency of an enterprise is determined by its ability and possibility to timely and fully fulfill payment obligations arising from trade, credit and other transactions of a monetary nature. Solvency affects the forms and conditions of commercial affairs, including the possibility of obtaining a loan. Liquidity of an enterprise is determined by the availability of liquid assets to it, which include cash, funds on bank accounts and easily realized elements of

19 Pokolenko V.O. Metodika vdoskonalennya manevrenosti, finansovoyi stijkosti ta dilovoyi aktivnosti virobnichoyi programi budivelnih pidryadnih organizacij shlyahom multikriterialnoyi optimizaciyi // Shlyahi pidvishennya efektivnosti budivnictva v umovah formuvannya rinkovih vidnosin. - Vip. 10. - 2002. - S. 65-80.

${ }^{20}$ Bielienkova O.Yu., Antropov Yu.V. Ekonomichna stijkist malih budivelnih pidpriyemstv Ukrayini: ocinka, tendenciyi, perspektivi Problemi ekonomiki. - 2013. - № 3. - S. 51-62.

${ }^{21}$ Ekonometrichnij instrumentarij upravlinnya finansovoyu bezpekoyu budivelnogo pidpriyemstva : [monogr.] / za nauk. red. d.e.n., prof. L. V. Sorokinoyi. - K. : Kiyivskij nacionalnij universitet budivnictva i arhitekturi; Krivij Rig : Vid. FOP Chernyavskij D. O., 2017. - C. 4-26.

${ }^{22}$ Izmajlova K. V., Byelyenkova O. Yu. Imitacijne modelyuvannya rozvitku budivelnogo pidpriyemstva [Elektronnij resurs] // Problemi sistemnogo pidhodu v ekonomici. - 2007. Vip. 4. - Rezhim dostupu: http : // www. nbuv. gov. ua/ e-journals / PSPE/20073/Belenkova_307.htm 
working capital. Liquidity reflects the ability of an entity to make the necessary costs at any time.

Liquidity and solvency as economic categories are not identical, but in practice they are closely interdependent. The liquidity of the enterprise reflects the solvency of the debt. Enterprise's failure to repay its debt to its creditors and the budget forces it into bankruptcy. The grounds for declaring a company bankrupt are not only their failure to fulfill their obligations to the budget within a few months, but also the failure to fulfill the requirements of legal entities and individuals having financial or property claims against it. Improving the solvency of an enterprise is inextricably linked to a working capital management policy aimed at minimizing financial liabilities. In other words, profit is a long-term goal, but in the short term, even a profitable business can go bankrupt due to lack of funds.

The following basic techniques can be used to assess solvency and liquidity:

a) structural analysis of changes in the active and passive Balance Payments, that is, the analysis of the liquidity of the balance;

b) calculation of financial liquidity ratios;

c) analysis of cash flows during the reporting period.

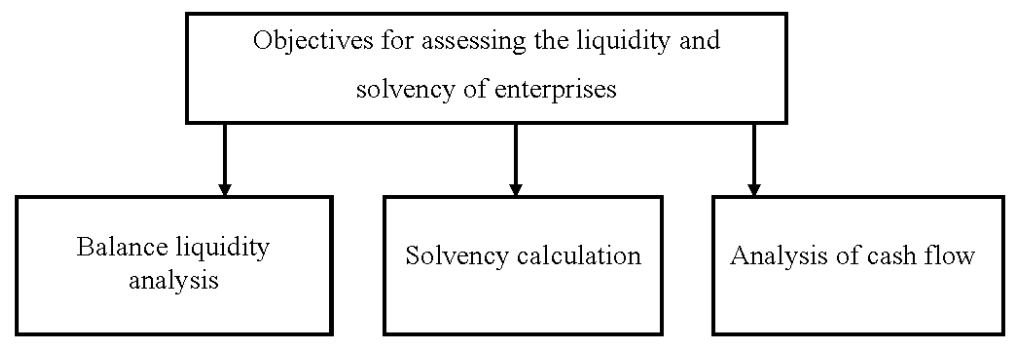

Fig. 1.1. Solvency and liquidity assessment tasks

While analyzing balance liquidity one compares the assets, grouped by degree of their liquidity, with liabilities for debit, (grouped by their maturity. Calculation and analysis of liquidity coefficients allows to identify the degree of security of current liabilities by liquidity funds. The main purpose of cash flow analysis - to evaluate the ability of the company to generate funds in the amount and in the time required to make the planned expenses and payments. The main task of assessing the accounting liquidity is to determine the amount of cover of the liabilities by an enterprise with its assets, whose term of transformation into monetary form (liquidity) corresponds to the term of repayment of liabilities (urgency of return). 
For analysis, the assets and liabilities of the balance are grouped by the following features ${ }^{23,24}$ :

- by the degree of liquidity reduction (assets);

- the degree of maturity (payment) (liabilities).

Assets, depending on the rate of conversion into funds (liquidity) are divided into the following groups:

A1 - the most liquid assets. These include cash from enterprises and short-term financial investments.

A2 - fast-selling assets: receivables for goods, services, accounts receivable and other current assets;

A3 - slow-moving assets - these include inventories and expenses, longterm financial investments;

A4 - hard-to-sell assets are defined as the difference between the value of non-current assets (total I section of assets) and long-term financial investments.

The grouping of liabilities occurs according to the degree of urgency of their return:

P1 - the forward liabilities - accounts payable for goods, works, and services, current settlement obligations, other current liabilities;

P2 - short-term liabilities which include short-term bank loans, current debt on long-term loans, promissory notes;

P3 - long-term liabilities. These include long-term bank loans, other long-term liabilities;

P4 - fixed liabilities. These are their own - summary of Sec. I of liabilities.

To provide the project investor (creditor) with a reliable and economically sound picture of the flow of project assets at different phases and elements of the investment cycle, an innovative model of multicriteria project valuation is proposed, which uses indicators of liquidity of projects and solvency of organizations as a leading requirement (criterion).

The following research methods and models were used as the methodological basis of the created model:

- system analysis - to determine the content and list of evaluation criteria and arguments that are part of the calculated evaluation criteria;

\footnotetext{
${ }^{23}$ Izmajlova K.V. Finansovyj analiz: Navchalnyj posibnyk - 2-ge vydannya, stereotypne K.: MAUP, 2001. $-152 \mathrm{~s}$.

24 Ekonometrichnij instrumentarij upravlinnya finansovoyu bezpekoyu budivelnogo pidpriyemstva : [monogr.] / za nauk. red. d.e.n., prof. L. V. Sorokinoyi. - K. : Kiyivskij nacionalnij universitet budivnictva i arhitekturi; Krivij Rig : Vid. FOP Chernyavskij D. O., 2017. - C. 4-26.
} 
- balance and structural method - for calculating values of model arguments based on the results of analysis of design estimates, feasibility studies, business plans, financial reporting on the results of the activities of organizations participating in the investment process;

- network models of «work-arc» with updated composition of parameters as the basis of process formalization of the investment cycle;

- models of optimization on several criteria and ways of their coordination.

The mathematical formalization of the problem is as follows. As model criteria it is suggested to use:

1) maximum of the immediate liquidity index of project $Z 1$ assets determined at the current moment of time by the ratio of the expert value of the finished finished product of the project and the unfinished construction to the volume of all obligations of the investor (co-investors) for the project (particles of unit);

2) the maximum of the absolute liquidity of the organizations-leading participants of the $\mathrm{Z} 2$ project - determined by the indexes of absolute liquidity of the investing organizations, in proportion to their shares in the assets (value) of the project at the moment (particles of unit);

3) maximum - the current liquidity of the leading participants of the $Z 3$ project - determined by the indexes of the current liquidity of investor organizations, in proportion to their shares in the assets (value) of the project at the moment (particles of unit);

4) maximum of the working capital of the investor organizations of the $\mathrm{Z} 4$ project, weighted average by their shares in the assets (value) of the project at the moment (UAH, in thousands)

$5)$ the minimum probability of bankruptcy of Z5 co-investor organizations is determined by the ratio of the difference between current assets and short-term liabilities to the balance sheet total for each of the coinvestor organizations, in proportion to their contribution to the value of all project assets (particles of unit).

6) the maximum turnover of project Z6 assets, determined by current periods (months or quarters), taking into account the time factor due to the ratio of the total volume of sales in value (excluding VAT, excise duties and other payments) to the value of all the assets invested in the project (units);

7) the maximum social efficiency of the $\mathrm{Z7}$ project, determined by the ratio of the amount of revenues to treasuries at all levels by way of value added tax, excise duties, other deductions from the volume of sales of products (services, BIS), income tax, payments to the payroll, to the estimated duration of the investment cycle, (UAH, in thousands / year);

Arguments (independent variables) for all calculation criteria are: 
- current time coordinates - months, quarters, years for which the investment situation for each of the submitted projects is examined;

- determined by periods the value of fixed and current assets invested in the project, taking into account the shares of co-investing organizations, UAH, in thousands;

- the volume of sales of the project products in terms of value (excluding VAT, excise duties and other payments), UAH, in thousands;

- total payroll for all types of work, costs, project participants at the current time, UAH, in thousands;

- total rate of aggregate payments to the payroll fund, particle of unit;

- profit (financial result) of economic activity of all participating organizations at the moment, $\mathrm{UAH}$, in thousands;

- the rate of taxation of profits, particle of unit.

In accordance with the defined content of criteria and arguments, the formulation of the problem, according to this economic model, reflects the following system of equations and inequalities (4):

$$
\begin{aligned}
& Z_{1}(t)=\left[s_{11}(t)+s_{12}(t)\right] / s_{13}(t) ; \\
& \mathbf{Z}_{2}(t)=\sum_{h=1-: H} \Omega_{h}\left[s_{21}(t, h)+s_{22}(t, h)\right] / s_{23}(t, h) ; \quad \Omega_{h}=W_{h} / W_{\Sigma} ; \\
& \mathbf{Z}_{3}(t)=\sum_{h=1:: H} \Omega_{h} s_{31}(t, h) / s_{32}(t, h) ; \quad s_{32}(t, h)=s_{23}(t, h) ; \\
& \mathbf{Z}_{4}(t)=\sum_{h=1: H} \boldsymbol{\Omega}_{\mathbf{h}}\left[\mathbf{s}_{41}(t, h)-\mathbf{s}_{42}(t, h)\right] ; \\
& s_{41}(t, h)=s_{31}(t, h) ; \quad s_{42}(t, h)=s_{43}(t, h) ; \\
& \mathbf{Z}_{5}(t)=\sum_{h=1: \mathrm{H}} \boldsymbol{\Omega}_{\mathrm{h}} \mathbf{s}_{51}(t, h) / \mathbf{s}_{52}(t, h) ; \mathbf{s}_{51}(t, h)=\mathbf{s}_{41}(t, h)-\mathbf{s}_{42}(t, h) ; \\
& \mathbf{Z}_{6}(t)=\sum_{t=1-:-T}(1 / t) *\left[\mathbf{s}_{61}(t)+\mathbf{s}_{62}(t)+\mathbf{s}_{63}(t)\right] /\left[\mathbf{s}_{64}(t) *\left(1+\alpha^{(\Delta t)}\right)\right] ; \\
& \Delta \mathbf{t}=\mathbf{t}-\mathbf{t}_{\mathbf{0}} \text {; } \\
& \mathbf{Z}_{7}(\mathbf{t})=\sum_{\mathbf{t}=1-:-\mathrm{T}}\left[\mathbf{s}_{71}(\mathbf{t})+\mathbf{s}_{72}(\mathbf{t})+\mathbf{s}_{73}(\mathbf{t})\right] / \mathbf{s}_{74}(\mathbf{t}) ; \quad \mathbf{s}_{74}(\mathbf{t})=\mathbf{s}_{61}(\mathbf{t}) ; \quad(4 . \mathrm{g}) \\
& \left\{\mathbf{Z}_{1}(\mathbf{t}), \mathbf{Z}_{2}(\mathbf{t}), \mathbf{Z}_{3}(\mathbf{t}), \mathbf{Z}_{\mathbf{4}}(\mathbf{t}), \mathbf{Z}_{6}(\mathbf{t})\right\} \rightarrow \max ; \quad \mathbf{Z}_{7}(\mathbf{t}) \rightarrow \min
\end{aligned}
$$


$\boldsymbol{\Omega}_{\mathrm{h}}$ - share of co-investor organizations in the total value of project assets;

$\mathbf{W}_{\Sigma}$ - the total cost of all investment in the project;

$\mathbf{W}_{\mathbf{h}}-$ the cost of the investment provided for investment by the h-th organization;

$\mathbf{s}_{11}-$ expert cost of the finished product created by the project;

$\mathbf{s}_{\mathbf{1 2}}$ - the same, unfinished construction;

$\mathbf{s}_{13}$ - cost of all commitments to the submitted project at the current time;

$\left[\mathbf{s}_{21}(\mathbf{t}, \mathbf{h})+\mathbf{s}_{\mathbf{2 2}}(\mathbf{t}, \mathbf{h})\right] / \mathbf{s}_{\mathbf{2 3}}(\mathbf{t}, \mathbf{h})$ is the absolute liquidity index of an h-th organization;

$\mathbf{s}_{21}(t, h), \mathbf{s}_{22}(t, h), \mathbf{s}_{23}(t, h)=\mathbf{s}_{32}(t, h)-$ respectively the cash, current financial investments and current liabilities of the $h$-th organization at time $t$;

$\mathbf{s}_{31}(t, h)=\mathbf{s}_{\mathbf{4 1}}(\mathbf{t}, \mathbf{h})$ - value of circulating assets of the h-th organization at time t;

$\mathbf{S}_{51}(\mathbf{t}, \mathbf{h})$ - the net working capital of an h-th organization at time $t$ is the difference between the value of current assets and current liabilities;

$\mathbf{S}_{\mathbf{5 2}}(\mathbf{t}, \mathbf{h})$ - a summary of the balance of the h-organization at time $t$;

$\mathbf{s}_{61}(\mathbf{t})$ - the volume of sales of products in terms of value under this project for the current period (excluding VAT, excise duties and other payments);

$\mathbf{s}_{\mathbf{6 2}}(\mathbf{t})$ and $\mathbf{s}_{\mathbf{6 3}}(\mathbf{t})$, respectively - the amounts of income tax and payroll contributions attributed to this project by all participating organizations;

$\mathbf{S}_{64}(\mathbf{t})$ - the amount of investment specified for investment in this project for the current period;

$\mathbf{t}_{\mathbf{0}}$ - is the period of time for which the value is adjusted (discounted);

$\left(\mathbf{1}+\boldsymbol{\alpha}^{(\Delta t)}\right)$ - is the denominator of discounting;

$\Delta \mathbf{t}-$ is the difference between the current time coordinate and $\mathrm{t}_{0}$.

Initial data for calculating model arguments is information on the structure of project assets (non-current, current) and sources of their financing (by investors), data on the components of the project cash flow (sales revenue, profitability of production and sales, salary, etc.), as well as information on the financial position of the leading participants in the investment process according to the public financial statements.

Based on the link between the content of $\mathbf{s}_{11^{-}}:-\mathbf{s}_{74}$ model arguments (dependent variables) in equations (1) - (4) with the volumes and structure of the estimated cost of projects, they can be presented as algebraic functions that combine the following investment characteristics (5):

$$
\left\{\mathbf{s}_{11^{-}:-s_{74}}\right\}=\mathbf{f}\left(\mathbf{W}_{\mathrm{mh}} ; \mathbf{X m o a} ; \mathbf{t}\right) \text {, }
$$




$$
\begin{aligned}
& \mathbf{W}_{\mathrm{mh}}=\boldsymbol{\Omega}_{\mathrm{mh}} * \mathbf{W}_{\mathrm{m}} * \boldsymbol{\delta}_{\mathrm{mh}} ; \sum_{\mathrm{m}=\mathrm{i}-:-\mathrm{M}} \sum_{\mathrm{h}=\mathrm{i}-:-\mathrm{H}} \mathbf{W}_{\mathrm{mh}}=\mathbf{W}_{\Sigma} ; \boldsymbol{\delta}_{\mathrm{mh}}=\{\mathbf{1} ; \mathbf{0}\}, \\
& \lambda_{\mathrm{m}}{ }^{\text {oa }}+\lambda_{\mathrm{m}}{ }^{\text {на }}=1 ; \lambda_{\mathrm{m}}{ }^{\text {oa }}=\mathbf{O A}_{\mathrm{m}} / \mathrm{W}_{\mathrm{m}} ; \lambda_{\mathrm{m}}{ }^{\text {на }}=\mathbf{H A} \mathbf{A}_{\mathrm{m}} / \mathbf{W}_{\mathrm{m}} ; \mathbf{H A}_{\mathrm{m}}+\mathbf{O A _ { m }}=\mathbf{W}_{\mathrm{m}}
\end{aligned}
$$

where $\mathbf{W}_{\mathbf{m h}}-$ is the anticipated amount of investment by the h-th organization of the $\mathrm{m}$-th construction project, which is proposed as a part of the investment program;

$\lambda_{m}{ }^{\text {ra }}$ - the share of non-current assets of the m-th project in its total value;

$\lambda_{\mathbf{m}}{ }^{\mathbf{a}}$ - the same for current assets;

$\boldsymbol{\delta}_{\mathbf{m h}}-$ an indicator of the h-th organization's involvement in the investment process of the $\mathrm{m}$-th construction project (if $\mathrm{h}$-th organization participates in the investment, then $\boldsymbol{\delta}_{\mathbf{m h}}=\mathbf{1}$, if not - then $\boldsymbol{\delta}_{\mathbf{m h}}=\mathbf{0}$ );

$\boldsymbol{\Omega}_{\mathbf{m h}}$ - the proportion of assets in the $\mathrm{m}$-th project that belongs to the h-th organization, the indicator of the distribution of project assets by their future owners;

$\mathrm{M}$ - number of projects in the investment program;

$\mathrm{H}$ - number of co-investor organizations participating in the investment program

Taking into account equations (4), the mathematical formulation of the problem in the form (5) is transformed into the form (6):

$$
\begin{gathered}
\mathbf{Z}_{\mathrm{i}}=\left\{\mathbf{Z}_{\mathrm{i}}(\mathbf{0})\right\}+\left\|\mathbf{a}_{\mathrm{ij}}\right\| * \mathbf{f}\left(\mathbf{W}_{\mathrm{mh}} ; \boldsymbol{\lambda} \mathbf{m}_{\mathrm{oa}} ; \mathbf{t}\right) ; \quad \mathrm{s}=\mathrm{l-:}-\mathbf{7} ; \mathbf{Z}_{\mathrm{i}}=\left\{\mathbf{Z}_{1}, \mathbf{Z}_{2}, \ldots, \mathbf{Z}_{7}\right\} \\
\mathbf{Z}_{\mathrm{i}}(\mathbf{0})=\mathbf{Z}_{\mathrm{i}} \text { при } \mathrm{t}=\mathbf{T 0}
\end{gathered}
$$

Where $\mathbf{Z}_{\mathbf{i}}$ - is the vector of criteria values;

$\mathbf{Z}_{\mathbf{i}}(\mathbf{0})$ - is the vector of initial conditions that determine the values of the benchmarks at the beginning of the $\mathbf{T}_{\mathbf{0}}$ investment process.

The optimal alternative to the investment program is sought by the individual criteria $\mathbf{Z}_{\mathbf{1}}, \mathbf{Z}_{\mathbf{2}}, \ldots, \mathbf{Z}_{\mathbf{7}}$ is sought using the monocriteria optimization algorithms $\mathbf{Z}_{\mathbf{1}}(\mathbf{t}), \mathbf{Z}_{\mathbf{2}}(\mathbf{t})-\mathbf{Z}_{\mathbf{4}}(\mathbf{t}), \mathbf{Z}_{6}(\mathbf{t}), \mathbf{Z}_{7}(\mathbf{t}) \rightarrow \max ; \mathbf{Z}_{5}(\mathbf{t}) \rightarrow$ min by changing the movable $\mathbf{W}_{\mathbf{m h}}$ parameters and the start times of the tm investment process for individual projects within the established limits as to these parameters and requirements as to the volume, structure, sources and intensity of investments.

The investment program that is optimal for all criteria is sought within the same limits by a linear combination of local solutions (7) using the weight coeffient Ui of the contributions of local $\mathbf{Z}^{\text {opt }}{ }_{\mathbf{i}}$ solutions to the total $\mathbf{Z}^{\text {opt. }}$ : 


$$
\mathbf{Z}^{\text {opt }}=\sum \check{\mathbf{U}}_{\mathbf{i}} * \mathbf{Z}^{\text {opt }} ; ; \quad \quad \mathbf{i}=1-:-7 ; \quad \check{\mathbf{U}}_{\mathrm{i}}=\mathbf{0 - : - 1 ;} \quad \sum \check{\mathbf{U}}_{\mathbf{i}}=\mathbf{1}
$$

The proposed model provides a sound scientific basis for selecting options for investment construction projects and resource and calendar models for their implementation. The proposed approach, due to the combination of local criteria of different content, ensures the growth of solvency and profitability of the activities of the leading participants of the investment process, and the conditions for ensuring high liquidity of project assets and their social efficiency.

\section{CONCLUSIONS}

The developed economic and mathematical model of liquidity management of construction investment assets offers an optimal alternative to the investment program sought by optimizing the structure and sources of investment. By local criteria, we seek to change the moving parameters of Wmh and the starting point of the investment process for individual projects within the limits set for these parameters, which reflect the requirements of ODA in terms of volume, structure, sources and intensity of investments.

4. The following are suggested as local criteria for optimization of investment programs:

I) maximum of the immediate liquidity index of project assets $Z_{1}-$ at the current moment determined by the ratio of the expert value of the created and finished product of the project and the unfinished construction to the volume of all obligations of the investor (co-investors) for this project (particles of unit);

II) maximum absolute liquidity of the organizations - the leading participants of the $Z_{2}$ project - determined by the absolute liquidity indices of the investor organizations, in proportion to their shares in the assets (value) of the project at the moment (particles of unit);

III) maximum - the current liquidity of the leading participants of the $Z_{3}$ project - determined by the indexes of the current liquidity of the investor organizations, and in proportion to their share in the assets (value) of the project at the current moment (particles of unit);

IV) maximum of the working capital of the investor organizations of the $\mathrm{Z}_{4}$ project, average weighted by their shares in the assets (value) of the project at the moment (UAH, in thousands);

$\mathrm{V})$ the minimum probability of bankruptcy of $\mathrm{Z}_{5}$ co-investor organizations is determined by the ratio of the difference between current assets and short-term liabilities to the balance sheet total for each of the co- 
investor organizations, in proportion to their contribution to the value of all project assets (units).

VI) maximum turnover of assets of project $Z_{6}$, determined by current periods (months or quarters), taking into account the time factor due to the ratio of the total volume of sales in terms of value (excluding VAT, excise duties and other payments) to the value of all assets invested in the project (units);

VII) maximum social efficiency of the $Z_{7}$ project, determined by the ratio of the amount of revenues to the budgets of different levels in the form of value added tax, excise duties, other deductions from the volume and sale of products (services, BIS), income tax, payments to the payroll, to estimated duration of the investment cycle, (UAH, in thousands / year);

The investment program that is optimal for all criteria is sought within the same constraints by a linear combination of local solutions using the weighting of the contribution of local solutions to the total. The proposed model provides a sound scientific basis for selecting options for investment construction projects and resource-calendar models for their implementation. The proposed approach, due to the combination of local criteria of different content, ensures the increase of solvency and profitability of the activities of the leading participants of the investment process, and the conditions for ensuring high liquidity of assets and projects and their social efficiency.

In order to create a reliable and scientifically sound picture of the investment cycle for the investor, a deterministic cost-asset-source model is developed, based on standard elements of network-determined work-arc models, but using a new parameter system. Parameters of the cost-assetsource model are subject to the requirements of ensuring liquidity, social efficiency, profitability and resource efficiency in accordance with the multifaceted basis of the previous model.

\section{SUMMARY}

The article provides an overview of theoretical prerequisites for developing economic and social appraisal system while forming a portfolio of construction investment projects. The author gives analysis of theoretical and practical approaches to the interpretation of the categories «liquidity», «liquidity of construction projects assets « «solvency», «solvency of the investor», prerequisites for the development of strategic aspects of the developer's future assets liquidity in combination with the efficiency of projects as a basis for reviewing the parametric framework for investment portfolio assessment. The article reviews theoretical and applied methods of project selection, such as discounting methods, integral indicators, project 
organizational and technological decision assessment, econometric models based on game theory, investment criteria balance, factor analysis, statistical consistency criteria of technological solutions and calendar optimization. The author defines investment priorities of building composition and structure of the investment portfolio which ensures the maximum possible efficiency of investments taking into account their liquidity requirements.

To provide the project investor (creditor) with a reliable and economically sound picture of the flow of project assets at different phases and elements of the investment cycle, an innovative model of multicriteria project assesment is proposed, which uses project liquidity indicators and solvency of organizations as a leading requirement (criterion). The methodological basis for the created model was system analysis, optimization models by several criteria and ways of their agreement.

The article considers one of the basic components of the proposed model - the model of matching the solvency of the investor with the assets liquidity of construction projects. In the future, this model is going to be supplemented by new developments, which will include the balance and structural method, and network models of «work-arc» with updated parameters as a basis for process formalization of investment cycle.

\section{REFERENCES}

1. Tetyana Marchuk, Dmytro Ryzhakov, Galyna Ryzhakova and Sergiy Stetsenko (2017). Identification of the basic elements of the innovationanalytical platform for energy efficiency in project financing. Investment Management and Financial Innovations Vol. 14(4), pp. 12-20.

2. Bielienkova O. Yu. Tendentsii rozvytku budivelnoi haluzi yak chynnyky formuvannia stratehichnoi konkurentospromozhnosti budivelnykh pidpryiemstv // Budivelne vyrobnytstvo. 2014. Vol. 57. P. 24-30.

3. Vakhovych I. V. Pidvyshchennia efektyvnosti upravlinnia biznesprotsesamy budivelnykh pidpryiemstv / I.V.Vakhovych : [tekst] // Budivelne vyrobnytstvo. - 2015. - № 59. - C. 3-6.

4. Zeltser R.Ia., Bielienkova O.Iu., Novak Ye., Dubinin D.V. tsyfrova transformatsiia protsesiv resursno-lohistychnoho ta orhanizatsiinostrukturnoho zabezpechennia budivnytstva. Nauka i innovatsii. 2019, № 5.

5. Tymoshenko O. V. Vyklyky ta zahrozy chetvertoi promyslovoi revoliutsii: naslidky dlia Ukrainy. Biznes Inform. - 2019. - № 2. - C. 21-29.

6. Izmailova Kateryna, Bielienkova Olga, Moholivets Anton. The essence of economic cycles and their impact on the financial stability of construction Nauk. pr. NDFI 2019; 2:139-150 
7. Bielienkova, O.Y. Tsifra, T.Y. and Shashko, M.M. (2010), «Implementation of international experience financing affordable housing through construction and savings banks in Ukraine», Problems systematic approach to the economy, vol. 3, available at: http://www.nbuv. gov.ua/ejournals/ PSPE/2010_3 /index.h.

8. Tytok V. V. Suchasnyi stan protsedury otrymannia zamovnykom budivnytstva dozvilnykh dokumentiv // Shliakhy pidvyshchennia efektyvnosti budivnytstva $\mathrm{v}$ umovakh formuvannia rynkovykh vidnosyn. 2012. Vol. 28. P. 142-150.

9. Sorokina L.V. Doslidzhennia ekonomichnykh vazheliv zabezpechennia rozvytku budivelnoi haluzi / L.V. Sorokina, A.F. Hoiko // Budivelne vyrobnytstvo. -2015 . - № 59. - C. 6-15.

10. Goiko A.F. Doslidzhennia zahroz investytsiinoi bezpeky budivelnykh pidpryiemstv. / L. V. Sorokina, A. F. Hoiko // Budivelne vyrobnytstvo. - 2016. - № 61. - S. 8-19.

11. Izmailova K.V. Vplyv nematerialnykh aktyviv, intelektualnoi skladovoi yikh vartosti, tekhnichnykh zasobiv IT, pidpryiemstva na tempy zrostanni chystoho dokhodu. Budivelne vyrobnytstvo 61/2, 2016. - S. 23-29.

12. Tsyfra T.Iu. Praktychnyi dosvid realizatsii mizhnarodnykh budivelnykh kontraktiv v Ukraini / T.Iu. Tsyfra // Budivelne vyrobnytstvo. 2017. - № 63/2 - S. 78-85.

13. Tsyfra T.Iu. Avansovi platezhi v mizhnarodnykh budivelnykh kontraktakh // Upravlinnia rozvytkom skladnykh system. - 2017. - 186-192.

14. Vplyv investytsiinoi aktyvnosti na obsiahy budivelnykh robit $\mathrm{v}$ Ukraini // O.Iu. Bielienkova / Shliakhy pidvyshchennia efektyvnosti budivnytstva $\mathrm{v}$ umovakh formuvannia rynkovykh vidnosyn.: $\mathrm{zb}$. naukovykh prats. - vyp.30. - 2013. - S. 17-26

15. Ivakhnenko I.S. Budivelnyi development yak instrument realizatsii derzhavnoi investytsiinoi polityky // Efektyvna ekonomika (elektronnyi zhurnal). - 2019. - № 1. - Rezhym dostupu: http://www.economy.nayka.com.ua/?op=1\&z

16. Lych. V.M. Proekty $\mathrm{v}$ haluzi infrastruktury: partnerstvo derzhavnoho ta pryvatnoho sektoriv: Monohrafiia. KNUBA. Vydannia 2-he, vypravlene ta dopovnene. - K.; SPD Pavlenko, 2017. - 320 s.

17. Dmytro Ryzhakov, Oksana Malykhina, Vadym Pokolenko, Chupryna Yurii. The identification of alternatives and changesin scenarios for the developmen to fregional build clusters //DmytroRyzhakov, OksanaMalykhina, VadymPokolenko, Chupryna Yurii // International Journal of Engineering \&Technology, Vol 7, No 4.8 (2018): Special Issue 8. 
18. Marchuk T., Ryzhakov D. Analysis of financing sources of projects development for Ukrainian enterprises // Zbirnyk naukovykh prats «Upravlinnia rozvytkom skladnykh system». - yp.. 31. - K.: KNUBA, 2017. - s. 166-170.

Information about the author: Stetsenko S. P., DSc in Economics, Associate Professor, Head of the Department of Construction Economics, Kyiv National University of Construction and Architecture 31, Povitroflotsky Ave., Kyiv, 03037, Ukraine 